\title{
Alone in the world? Imago Dei from theological anthropology to Christology
}

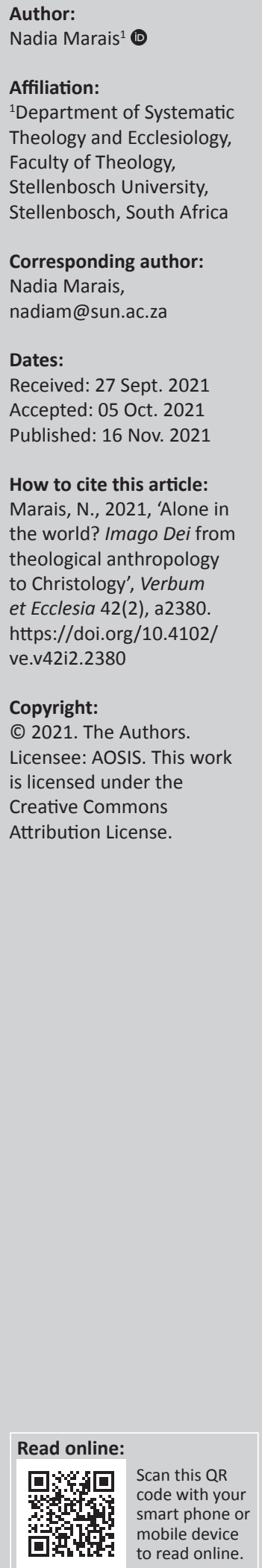

In Princeton theologian Van Huyssteen's (2006) major interdisciplinary work, Alone in the World? Human Uniqueness in Science and Theology, human uniqueness is rhetorically coupled with human aloneness. A comparison with a contemporary theological anthropology, namely Yale theologian Kelsey's (2009) Eccentric Existence: A Theological Anthropology, shows an alternative approach to the notion or concept of the imago Dei, namely a theological shift from viewing human beings as image(s) of God, to viewing human beings as images of Christ, or images of the image of God. This contribution responds to the invitation implied in Van Huyssteen's book title - are we alone in the world? - by exploring some of the rhetorical implications of a Christological interpretation of the imago Dei. One such implication may imply a different answer to Van Huyssteen's question - are we alone in the world?; not yes, but no. Dietrich Bonhoeffer's idea of Christ's promeity illustrates how the rhetorical dynamics behind such a move in response - from yes to no-may potentially look, and that a rearticulation of human uniqueness could have direct consequences for how we imagine our human aloneness in the world.

Intradisciplinary and/or interdisciplinary implications: This article contributes to a specifically intradisciplinary conversation in Systematic Theology, on reading and interpreting the notion or theological idea of human beings being created in the image of God. This article does this through a close reading and comparison of two interdisciplinary projects on what it means to be human, namely Van Huyssteen's Alone in the World? and Kelsey's Eccentric Existence.

Keywords: Wentzel van Huyssteen; David Kelsey; theological anthropology; Christology; imago Dei.

\section{Introduction}

Wentzel van Huyssteen's major interdisciplinary work dealing with human uniqueness in science and theology asks one crucial question - a question which is also the title of this book publication namely: Are we alone in the world? This is an intriguing question, notes David Fergusson, because it sets Van Huyssteen's Gifford Lectures in what he calls an 'interrogative mode'. ${ }^{1}$ However, perhaps the question mark in this book title also implies an invitation, in that it invites further engagement and reflection on the human condition of aloneness; and perhaps the 'tone' or 'mode' of this project could therefore also be described as 'invitational'.

This contribution was piqued by interest in this question that Van Huyssteen (2006) raises, and is therefore a response not only to the question mark in Alone in the world?, but also an attempt to engage the very question itself: are we, human beings, alone in the world? What is the rhetorical effect of this question - with its central focus on aloneness - and what may be the

1.See Fergusson's engagement with Van Huyssteen's (cf. 2015:194) book in an article entitled: "Are we alone? And does it matter? Fergusson described Van Huyssteen's project as 'a tentative exercise in a kind of natural theology' (Van Huyssteen 2015:195), which is a really interesting description in the light of Lord Gifford's demand - cited in Van Huyssteen's first chapter (2006:2), entitled: 'Human uniqueness as an interdisciplinary problem?' - for 'a generally conceived natural theology'. Van Huyssteen arguably meets this demand by presenting 'the "image of God" as having emerged from nature by natural evolutionary processes' (Van Huyssteen 2006:xviii). Indeed (Kelsey 2009:900), '[w]hile the phrase is not used extensively in either Testament, it appears relatively less frequently in the Old Testament and is put to no theological use in the Old Testament outside of Genesis. Although use of the phrase in Genesis does suggest some very general themes a some very general themes of anthropological significance, , that the most careful and in " "iml exe accounts of what human being is'.

Note: The title of this contribution is borrowed from Van Huyssteen's (2006) well-known theological anthropology, entitled Alone in the world? Human uniqueness in science and theology. The subtitle for this contribution comes from an article in which Van Huyssteen (cf. 2010b:150) reflects on the relationship between theological anthropology, ethics, and Christology, entitled 'What makes us human? The interdisciplinary challenge to theological anthropology and Christology'. In this article one of the headings reads: 'From theological anthropology to Christology?'

Note: Special Collection: Festschrift for Wentzel van Huyssteen 
practical, pastoral consequences behind asking this question in this way?

Fergusson (cf. 2015:194) suggested that some rethinking may be required, particularly with regards to Van Huyssteen's outline of the imago Dei in relation to the doctrines of the incarnation, providence, and eschatology, respectively. More particularly, to a theological audience it may sound strange to not engage Christology, in reflecting upon our human condition of aloneness, as a proximate doctrinal locus to that of theological anthropology - especially since the theological idea of the imago Dei again emerges in the New Testament, with reference to Jesus Christ. Indeed, Van Huyssteen (2006) recognised this himself, as evident in the articles published shortly after the publication of Alone in the World?, wherein he pays closer attention to Christology (See, for instance, Van Huyssteen 2008a, 2010a, 2010b).

Moreover, a brief comparison of Wentzel van Huyssteen's project with another major contemporaneous project in theological anthropology, namely Kelsey's (2009) Eccentric Existence, could illustrate how theological responses to the question - Are we alone in the world? - may vary, depending on the place, or the loci within a faith tradition, from which we reflect and speak. Theological traditions are, after all, fundamentally pragmatic' in behaviour (Van Huyssteen 2006:149), and in this sense shares the concern with practicality that 'human reasoning' does (Van Huyssteen 2008b:513). ${ }^{2}$

\section{The hermeneutical dilemma of 'being alone'}

In an article with the subtitle: "The "imago Dei" in the kinship of all creatures', Muray (2007:308) argued that it is of the utmost importance that we develop theological anthropologies that can meet and respond to the challenges of our times - including the ecological crisis. Yet it is his 'pragmatic concern' with the rhetoric of human uniqueness that has highlighted something of the problematic theological assumptions and implications behind the question regarding 'human aloneness'. Muray (2007) wrote that the question, are we alone in the world? is neither innocent nor neutral, for it evokes something in the reader:

A sense of 'being thrown into the world', of not belonging, of the absurd, of anxiety, [which] are very much part of the experiences of human beings. Nevertheless... this sense of not belonging to the universe, as real as it is, is symptomatic of the larger problem of our alienation from the non-human natural world. The creative transformation of that alienation into a sense of belonging, of not being alone in the universe, of being distinct yet alone being kin with all living beings, is what we need if we are to save our planet. (p. 309)

2.For Van Huyssteen, "human reasoning [or transversal reasoning] emerges as a practical skill' within interdisciplinary discourse in that it 'enables us to gather and bind together the patterns of our daily experiences' in a way that may help us 'make sense of them through communal, interactive dialogue' (Van Huyssteen 2008b:513). Stated somewhat differently, a public, interdisciplinary theology (cf. Van Huyssteen $2010 \mathrm{~b}: 143,157)$ requires a form of rationality, as 'a skill that enables us to gathe and bind together the patterns of our interpreted experience through rhetoric, 'articulation, and discernment' (Van Huyssteen 2008b:512). Transversality - o 'transversal reasoning', or 'transversal performance' - herein 'emerges as a heuristic device', which is to say 'a way to describe what actually happens in the performative praxis of our interdisciplinary reasoning' (Van Huyssteen 2008b:512-513).
Thus Wentzel van Huyssteen's book title, and all that it may evoke in and for us, accompanies us into a rich theological conversation on 'being alone', since he himself presents various responses to the question that his book title poses, namely: Are we alone in the world? Stated somewhat differently, being alone in the world' means different things for and within different disciplines and academic traditions, and as such we may need to trace some of these responses towards a fuller, richer exploration of the hermeneutical dilemma of 'being alone'.

A first response that Van Huyssteen offers to this question is a theological response - yes, we alone are created in the image of God, and we are therefore (positively) alone as unique among all living beings, including all animals and plants. Indeed (Van Huyssteen 2006):

In the Genesis texts the primal human being is seen as the significant forerunner of humanity, and as such defines the relationship between humanity and deity... we humans are therefore the culminating achievement of God: alone of all the creatures, we are said to be made in God's image. Alone of all the mammals, alone of all the plants, we are invited into a personal relationship with God... and in this theological sense we are indeed 'alone in the world ...'. (p. 121; my emphasis - NM.)

A second response is a paleoanthropological response - yes, we alone remain among the hominid species on this planet, and we are therefore (negatively) alone as the lone survivors among Homo sapiens and Homo neanderthalenis. In Van Huyssteen's (2006) own words:

$[T]$ his biblical perspective on human uniqueness differs strikingly from paleoanthropological views on humanness, where 'alone in the world' unambiguously points to the fact that we humans are in reality the last of the hominids on this planet (p. 121; my emphasis - NM.)

Yet, arguably Van Huyssteen provides a third 'yes' to the question about human aloneness in the world, namely a philosophical response - yes, we alone have the capacity for symbolic thought, language, art, and imagination; and we are therefore (positively) alone as special or unique among all life-forms. In Van Huyssteen's (2006) words:

$[H]$ uman beings are truly unique in having language and in possessing the apparatus that permits them to acquire and express it ... [This] is directly linked with the dramatic evidence for art, music, and symbol very early on in the history of our species. It is precisely this symbolism that lies at the very heart of what it means to be human. In fact, if there is one single thing that distinguishes humans from all other life-forms, living or extinct, it is the capacity for symbolic thought, the ability to generate complex mental symbols and to manipulate them into new combinations... this is the very foundation of imagination and creativity, of the unique ability of humans to create a world in the mind and then re-create it in the real world outside themselves. (p. 190)

Yes, yes, and yes - for Van Huyssteen, over and over this particular interdisciplinary conversation on human uniqueness seems to confirm that we are indeed alone in the world.

Yet how would theologians respond to this question if the place from which this question is asked would move from 
the doctrinal locus of creation (with its primary interest in Genesis 1-11 texts, with their portrayal of Adam and Eve as imago Dei) to the doctrinal locus of Christology (with its primary interest in New Testament texts that portray Jesus, not humanity, as the definitive imago Dei). Would a theological response to this question - Are we alone in the world? change if the locus from which theology's response within this transversal, interdisciplinary conversation is drawn is not creation, but Christology?

A parallel reading with Kelsey's (2009) recently published theological anthropology, entitled Eccentric Existence, ${ }^{3}$ might illustrate how a different theological approach to the imago Dei would lead to a slightly different logic of speaking, a different theological rhetoric, about human uniqueness and its possible implications for our human aloneness in the world. After all, for Van Huyssteen (2010b:144) himself 'theological rationality', as an expression of 'public, theological inquiry', includes both discursive and non-discursive dimensions, and as such includes a concern for rhetoric and the performance of articulation in language, conversation, intellectual reflection' (Van Huyssteen 2010b:144).

\section{Images of the image of God}

We return to the pivotal question of Wentzel van Huyssteen's work on human uniqueness; and one of the questions that arguably provide the focus and drive for his exploration of possible ways in which to pursue interdisciplinary dialogue on what it means to be human. Are we alone in the world? Yet, this very question also invites further theological engagement, since - as Durand (1981:128) noted in his Skepping, Mens, Voorsienigheid - the 20th century could rightly be described by what he calls 'the anthropocentric turn'. ${ }^{4}$

Jaap Durand's observation above - namely, that we live in the age of human beings, wherein a gradual and steadily increasing interest in human beings can be discerned, from the Renaissance and Reformation, and through the Enlightenment - perhaps provides us with an explanation for this increased and increasing concern with what it means to be human. It should therefore come as no surprise that a

3.It is worth noting here that Kelsey builds on the work done by his colleague at the Yale Divinity School, Frei (2013), entitled: The Identity of Jesus Christ (cf. Kelsey 2009:613, $680,683-688$ ). Interestingly, Frei (cf. 2013:51-57) argued that 'identity' is 'a person's uniqueness'. By this he meant 'the very "core" of a person towards which everything else is ordered, like spokes to the centre of a wheel... It is something which, if one knows it, provides the "clue" to a person' (Frei 2013:52). Identity, in other words, 'is knows it, provides the "clue" to a person' (Frei 2013:52). Identity, in other words, 'is
the specific uniqueness of a person, what really counts about him [sic]' (Frei 2013:52).

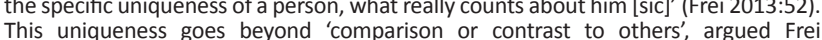
(2013:52), for '[o]ne person may... be the possessor of qualities, even physical properties, that are almost identical to those of another, yet each of them has his [sic] own identity'. It is this part of Frei's work - namely, where he explores (personal) uniqueness - that Kelsey draws on for his description of Jesus' 'unique, persona unsubstitutability, actions in which he is most fully himself' (cf. Kelsey 2009:613).

4.A longer quotation may be necessary here: 'Sonder vrees vir teenspraak kan beweer word dat die twintigste eeu by uitstek die eeu is waarin die mens en die vraag na wat die mens is, weer in die sentrum van die belangstelling te staan gekom het. Nie alleen in die karakteristieke geestesstrominge van ons tyd vorm 'n spesifieke mensbeeld die middelpunt waarheen telkens weer teruggekeer word nie, maar ook op natuurwetenskaplike terrein word die mens meer en meer objek van teoretiese analises en selfs van praktiese eksperimente. Dit wil natuurlik nie sê dat die

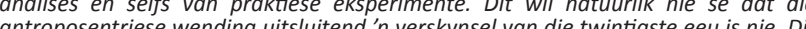
antroposentriese wending uitsluitend $n$ verskynsel van die twintigste eeu is nie. Dit sal verlengde le van 'n proses wat hom met die Verligting van die 17de en 18de eeu begin aanmeld het. Trouens, ons kan die antroposentriese tendens nog vroeër dateer, naamlik in die Renaissance, as dit nie was dat die Reformasie tussenin gekom en die vloedgolf teëgehou het nie' (Durand 1981:128). number of recent major works in theological anthropology have been published, including Princeton theologian Van Huyssteen's (2006) Alone in the World? and Yale theologian Kelsey's (2009) Eccentric Existence. ${ }^{5}$

How do other theological anthropologies, and other theologians, respond to what it means to be human? For one, other theological anthropologies - such as David Kelsey's theological anthropology - work with different root questions. For Kelsey (cf. 2009:159), the root question of his theological anthropology is not so much 'Are we alone in the world?', but rather: 'What does the specifically Christian conviction that God actively relates to us imply about what and who we are and how we are to be?'

One of the major points of overlap in these two projects would be the concern for interdisciplinarity. For Van Huyssteen (cf. 2006:xiv, 10), human uniqueness becomes the case study to which he applies his earlier worked out interdisciplinary methodology, which he calls 'postfoundationalist view of rationality'. For Kelsey (cf. 2009:67), 'what it is to be human' becomes the focus of what he initially intended as a 'an exercise intertraditional conversation' with other religious traditions and various sciences. Both Van Huyssteen and Kelsey centre their projects around a revision of the meaning of human beings as imago Dei.

One of the major differences between these two projects would lie in follow through on these intended interdisciplinary or inter-traditional works on anthropology. Kelsey (2009:7) wrote as follows, with regards to his choice to eventually abandon this project for a specifically theological project, that he realised that he 'needed to formulate the theological end of the bridge' before he could 'undertake the bridge-building project'. As such, Kelsey - unlike Van Huyssteen (Kelsey 2009:7) - opted for 'A Christianly particularist anthropology'. This 'alternative way' that Kelsey (2009:901) envisions, proposed that 'Christian anthropological claims [be explored] by reference to NT rather than OT uses of the phrase "imago Dei"'. As Kelsey noted, this exact approach is evident in various recent theological anthropologies. ${ }^{6}$

5.Interestingly, even though Van Huysteen and Kelsey would publish their major works within 3 years of one another, neither of them refer to the work of the other. 'Eccentric existence' makes no mention of any of Van Huyssteen's publications, including 'Alone in the world?'; nor does Van Huyssteen refers Kelsey in later article publications in theological anthropolic publications in theological anthropology, such as his essay entitled 'What makes us human?' (2010b). See The Theological Anthropology of David Kelsey (ed. Outka 2016) for a series of published responses to his book, as well as the published responses to Wentzel van Huyssteen's book in Theology Today (volume 78, issue 2 July 2015; including Wentzel van Huyssteen's response entitled 'A response to my colleagues' 2015), Zygon (volume 43, issue 2, June 2008; including Van Huyssteen's response entitled 'Primates, hominids, and humans - From species specificity to human uUniqueness?' 2008b), as well as in Human origins and the Image of God (eds. Lilley \& Pedersen 2017)

6.Examples include Kelsey (2009:901), Mary McClintock Fulkerson's feminist account of the imago Dei (cf. Fulkerson 1997), Stanley Grenz's trinitarian theology of the imago Dei (cf. Grenz 2001), Alistair McFadyen's exploration of human personhood (cf. McFadyen 1990), and lan McFarland's exploration of human identity (cf. McFarland 2001). Among these, Stanley Grenz's book is for Kelsey 'the most fully worked-out 2001). Among these, Stanley Grenz's book is for Kelsey the most fully worked-out contemporary version of the Christocentric approach to the meaning of imago Dei in 'Christian theological anthropology' (Kelsey 2009:902). Kelsey noted (2009:901) that '[t]here are important theological differences among these recent theological anthropologies that interpret the phrase "image of God" christocentrically", and that they also differ from his own project in various ways. Yet there are also important shared elements, including with his book, such as 'the judgment that focus on the imago Dei, interpreted christocentrically, can exhibit the systematic interconnections among the claims made in theological anthropology' (Kesley 2009:902). 
An interesting and notable theological difference between these two projects have to do with the role and placement of the notion of the imago Dei. For Van Huyssteen (2006:117), 'the doctrine of the imago Dei' is 'one of the most enduring, core traditions of the Christian faith', and a particularly theological articulation of human uniqueness. As such, Van Huyssteen's (2006:159) theological treatise on human uniqueness is closely associated with 'the powerful biblical claim that humans are created in the image of God', particularly as encountered in Genesis 1-11.?

A hermeneutical key to Van Huyssteen's theological argument is the primary biblical text(s) that he employed. Upon a first reading, it may appear that the classic text of Genesis 1:26-28 functions as the hermeneutical heartbeat to Van Huyssteen's transversal reading of what it means to be imago Dei (cf. Van Huyssteen 2006:118-123). This would be the expected route, since so many theological anthropologies rely heavily upon these three verses (and verse 26 in particular), as noted by Kelsey (2009:895). ${ }^{8}$

However, a closer rhetorical reading may reveal that it is not (only) Genesis 1:26-28 that deeply shapes the priorities and contours of Van Huyssteen's theological rhetoric, but three key Hebrew texts that include references to the imago Dei, including Genesis 9:1-17 (Van Huyssteen 2006:120, 123) and Genesis 5:1-3 (Kelsey 2009:922-923). Yet, it is Genesis 3:22 in particular (with its allusion to the emergence of moral awareness) that functions as a primary hermeneutical lens in Van Huyssteen's theological account of what it means to be human (Van Huyssteen 2008b:515). ${ }^{9}$ Indeed according to Van Huyssteen (2006):

$[I] \mathrm{n}$ this important text is embedded the most comprehensive meaning of the biblical notion of the imago Dei. Here, in the emergence of an embodied moral awareness, and a holistic, new way of knowing, lies the deepest meaning of the notion of the image of God. (p. 160)

7.Van Huyssteen does note - strikingly similar to some of Kelsey's remarks, in this regard - the hermeneutic challenges behind such a central theological notion
resting on such scarce, sparse Scriptural references: 'Scriptural references to the creation of humans in the image of God are clearly few and far between, and thei meaning has always been controversial' (Van Huyssteen 2006:117). In a section entitled: 'Theological reasons for not privileging Genesis 1-3' (cf. Kesley 2009:186) Kelsey argued that 'the force of Genesis $1-11$ as a whole is ordered to the Pentateuch's story of God's event of deliverance', and that the creation account here are therefore 'bent' by the logic of deliverance (Kesley 2009:188). Stated somewhat differently, Kelsey's major concern with employing these texts - and Genesis 1:26-28 in particular - as central texts in a working out a theological anthropology, lies therein that these texts are not what they seem, on surface level: they are not governed by the logic of God creating human beings, but instead governed by the logic of God saving human beings. Exactly this crossing of theological implications of these texts for answering the question: what does it mean to be a human being?

8.Kelsey wrote that ' $[t]$ he array of different types of claims about human being that are traditionally made in Christian theological anthropology have been held together by showing how they all tie into a central claim derived from Genesis 1:26a... [The imago Dei] was traditionally understood to be some essential structura feature of human beings that constitutes them as distinctively human and distinguishes them from animals who do not exhibit God's image. Usually the image of God was identified with the rationality and the freedom presupposed by mora accountability that instinct-driven animals lack

9.Wentzel van Huyssteen does see a particular dynamic between these two texts that shape 'all discussions of the meaning of the "image of God" texts in the Old Testament literature', and argued that 'Genesis 1:26 and 3:22 should be seen as powerfully interacting with one another' (Van Huyssteen 2006:123). Yet, as important as Genesis 1:26-28 are in introducing the idea of the 'first humans' that are created in the image of God, Van Huyssteen's argument required Genesis 3:22,

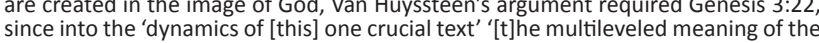
notion of the imago Dei... [was] transversally integrated' (Van Huyssteen 2006:160)
In other words, for Van Huyssteen (2008b:515) the notion ('not doctrine') $)^{10}$ of the imago Dei finds its most fruitful expression - within the context of interdisciplinary discourse on what it means to be human - in Genesis 3:22, because this specific text strengthens Van Huyssteen's argument that we should interpret 'the notion of Homo sapiens as moral human beings'.

For Kelsey (2009:900), however, it is important to not only augment Old Testament references to the imago Dei with New Testament references to Jesus Christ as the imago Dei; but to go even further: 'to privilege New Testament uses, rather than Old Testament uses, of the phrase "image of God" in relation to Christian theological anthropology'. ${ }^{12}$ His reason for such privileging has to do with the richer rhetorical and theological potential of New Testament references to (Jesus Christ as) the image of God (Kelsey 2009:901). As such, his approach leads him to present human beings not as image of God, but instead images of the image of God (Kelsey 2009:1009). For Kelsey (cf. 2009:907), Jesus Christ is the 'definitive' image of God, whereas human beings are the 'derivative' image of God. Indeed for Kesley (2009:1009), human beings not bearing the image of God themselves, nonetheless image the image of God.

For Kelsey (cf. 2009:1009), because Jesus is the image of God, human beings are 'imagers of the image of God' as imagers of Jesus. In short, this means that human beings reflect the mystery of the triune God, making us 'finite living mysteries that image the triune living mystery' (Kelsey 2009:1009). For Kelsey (2009:1010), Jesus is 'the paradigmatic human creature' through whom human beings image the image of God, in a threefold manner: (1) by living on borrowed breath, (2) by living on borrowed time, and (3) by living by another's death.

10.Wentzel van Huyssteen maintained this important rhetorical distinction throughout his work (cf. for instance Van Huyssteen 2008b:515, wherein he makes this distinction explicit: 'the notion (not doctrine) of the image of God'. He takes great
care with the rhetoric he employed, and this is one key example of his concern with care with the rhetoric he employed, and this is one key example of his concern with
language. David Kelsey is also critical of how the theological idea that human language. David Kelsey is also critical of how the theological idea that human
beings are imago Dei has been reworked into a doctrine, and to what ends this beings are imago Dei has been reworked into a doctrine, and to what ends this
'doctrine of the imago Dei' is used for. He wrote (Kelsey 2009:895-896) that 'it has been easy to systematize theological anthropology by making a doctrine of the imago Dei the conceptual framework in which other types of claims... can be explained'. Yet, as Kelsey notes (2009:896), '[t]his way of systematically organizing theological anthropology around the concept of the imago Dei remained dominan in Christian theology well into the middle of the twentieth century'.

11.It should be noted that Wentzel van Huyssteen does include New Testament references to Jesus of Nazareth as the image of God, including Colossians 1:15, 2 Corinthians 4:4, and 2 Corinthians 3:1-8) (cf. Van Huyssteen 2006:123-125). He wrote (Van Huyssteen 2006:124) that 'Jesus Christ now [in these texts] so absolutely preempts the role of image of God that the vocation and destiny of human beings can be realized only through a transformation of their existence by his Spirit. Indeed (Van Huyssteen 2006:124), "[t]his structural theme of the "image of God" in the texts of the New Testament also reflects a remarkable continuity with the Old Testament texts, and Jesus is now identified as the one who, like the with the Old Testament texts, and Jesus is now identified as the one who, like the
primal human before him, defines the relationship between humanity and God'. David Kelsey builds his account of 'Jesus Christ as the Image of God' (Kelsey 2009:905-921) on many of the same New Testament texts that Van Huyssteen included in his discussion of New Testament references to Jesus as the image of God, including 2 Corinthians 4:4, Colossians 1:15, and Hebrews 1:3 (cf. Kelsey 2009:905). These 'three texts identify Christ with the image of God in different regards', wrote Kelsey (2009:905).

12. Indeed (Kelsey 2009:900), '[w]hile the phrase is not used extensively in either Testament, it appears relatively less frequently in the Old Testament and is put to no theological use in the Old Testament outside of Genesis. Although use of the phrase in Genesis does suggest some very general themes of anthropological significance, interpretation of the key text (Gn 1:26-28) is so problematic and controversial that the most careful and influential exegeses seem to cancel out each other. Exegetical debates about Genesis 1:26-28 are simply too inconclusive each other. Exegetical debates about Genesis 1:26-28 are simply too inconclusive
to warrant giving "image of God" the central, anchorlike role it has traditionally played in theological anthropology's accounts of what human being is'. 
So, whereas Van Huyssteen worked primarily with the Old Testament references to human beings as imago Dei (augmented by some references to the New Testament's portrayals of Jesus of Nazareth as image of God, such as in Heb 2:6-8) (cf. 2006:123-124), Kelsey (2009:907) worked primarily with New Testament portrayals of Jesus as 'the definitive image of God', in the light of which 'all one's previous understandings of God' may be 'critique[d] and, if necessary, revise[d], convert[ed], and reform[ed] ${ }^{\prime} .^{13}$

Moreover, in each of the New Testament texts 'the phrase "image of God" is introduced in the context of the authors offering pastoral exhortation' (Kelsey 2009:1003). The New Testament references to imago Dei, unlike the Old Testament references to imago Dei, are framed pastorally. This arguably indicates that the theological idea of imago $\mathrm{Dei}$ is also shaped by the rhetorical key or tone in which it is cast, and that a specifically Christological interpretation of the imago Dei lends itself to a concern with everyday human living.

To a certain degree, Kelsey's (2009:143) move to (re)interpret the notion of imago Dei Christo-centrically resonated with Van Huyssteen's project, since Van Huyssteen himself linked the emerging 'moral awareness' of human beings with the New Testament portrayal of 'Jesus as the true image of God'. ${ }^{14}$ Yet, Van Huyssteen (2006:143) is also critical of 'transposing' the imago Dei 'into eschatological, trinitarian language', for while it 'may have powerful intradisciplinary relevance', it may be risky for interdisciplinary dialogue, insofar as it may become increasingly abstract and be in danger 'of a loss of a transversal connection to the multilayered meaning of the original texts that inspired the doctrine of the imago Dei' (Van Huyssteen 2006:144).

Since the 'notion' (Van Huyssteen) or 'concept' (Kelsey) of imago Dei is not available to David Kelsey's project - at least not as an organising principle for theological anthropology -

13.In short for Kelsey "Jesus Christ in his concrete living hum.......................... is the decisive, if ambiguous, imago Dei' (Kelsey 2009:911). This is a direct result of Kelsey's conscious, deliberate (if 'basic', according to him) methodological move to identify the image of God with Christ; and in this sense, Kelsey admitted that his 'anthropological project clearly is christocentric in a certain way at the meta level' (Kelsey 2009:908). By this he meant that 'it is guided and normed by a christocentric understanding of the imago Dei at the level of its construal of the task of formulating theological anthropological proposals and some of the criteria of what count as good arguments for or against such proposals' (Kelsey 2009:909). Kelsey elaborated on this by also explaining how his project is not Christo-centric in other ways (even if it may be Christo-centric in the specific way outlined ac in other ways (even if it may be Christo-centric in the specific way outlined above): "the method of this project, guided by NT texts that identify the image of God with Jesus Christ, is not christocentric in two other ways that have been prominent in the practice of 'Christian secondary theology' (Kelsey 2009:909-910). Firstly, Kelsey's project is "not christocentric in the sense that it is warranted by the claim that Christ is the name of a single ultimate cosmological principle, a cosmic Chris principle in virtue of which the cosmos has both reality and unity or coherent wholeness' (Kelsey 2009:910). Secondly, Kelsey's project is 'not christocentric... in the sense that it is warranted by christocentric claims about the nature of "revelation" - namely, that Jesus Christ is either (1) the decisive revelation of God or... (2) the exclusive revelation of God' (Kelsey 2009:910). In short, the method of Kelsey's project is not determined by 'an ontological "christo-monist" premise' (Kelsey 2009:910).

14.A longer quotation may be helpful here (cf. Van Huyssteen 2006:143): '[W]e are the created image of God; and not only as God's walking representatives on earth, but also by imaging God in our "knowing of good and evil" (Gn 3:22), through our amazing ability for moral awareness, with all the creative and tragic consequences this has had for the ambiguous history of our species. This enigmatic, ambivalent nature of embodied human nature, the dissonance between being granted special status by God and at the same time "falling upwards"... into moral awareness by "knowing good and evil", should of course be linked to the New Testament idea of "knowing good and evil", should
Jesus as the true image of God'. an alternative logic for arranging or systematising theological anthropology is proposed: namely, 'a christological interpretation of the imago Dei [which] can hold... this anthropology together to show that, precisely by imaging the imago Dei, human eccentric existence itself has a wholenessin-complexity' (Kelsey 2009:896). In short, Kelsey (2009) argues that:

$[T]$ he image of God is not a general property of human beings as God's creatures but is rather the concrete person of Jesus Christ in his own unsubstitutable personal identity. (p. 896)

A christological interpretation could possibly offer an alternative theological response to the dilemma of human aloneness, in that (1) it moves away from essentialist views of being human and towards constructivist views of being human, ${ }^{15}$ and (2) ultimately arrives not at a yes, but a no: no, we human beings are not alone. Insofar as Jesus Christ is the (only) image of God, and insofar as we human beings are images of Jesus Christ - or images of the image of God - it is, in this reading, Jesus Christ (only) who is alone in all the world.

\section{From theological anthropology to Christology?}

Are we alone in the world? I would like to imagine that this question not only invites deeper theological reflection on the theological idea of the imago Dei, but also its rhetorical, pastoral implications for how human beings are to live and go on living in this world. For the German theologian Dietrich Bonhoeffer, Christian theology's response to this question, for instance, is - and should be - a Christo-logical response. For Bonhoeffer (cf. 2009:60), the idea of Christ's promeity is here of crucial importance. ${ }^{16}$ Christ is, after all, the one who stands pro me: 'in my place, where I should stand, but cannot ... on the boundary of my existence, beyond my existence, yet for me' (Bonhoeffer 2009:60). 'The boundary', writes Bonhoeffer (2009):

[L]ies between me and me, the old and the new ' $\mathrm{I}$ '. It is in the encounter with this boundary that I shall be judged. At this place, I cannot stand alone. At this place stands Christ, between me and me, the old and the new existence... In Christ, man [sic] recognizes it and thereby at the same time finds his [sic] new centre again. (p. 60)

For Bonhoeffer (cf. 2009:60-61), human beings are therefore not alone in the world, because Christ forms the centre of

15.As Kelsey noted, "Christ" is not the (religious?) name of a universal cosmological principle' but [in the three New Testament references to Christ as the image of God] instead 'the name of a concrete living human personal body in his distinctive relationship to God' (Kelsey 2009:906). The image of God is, in other words, 'Jesus Christ in his unsubstitutable human personal identity' (Kelsey 2009:906). This echoes Van Huyssteen's concern with [in appealing to the three Old Testament references to human beings as the image of God, in particular] interpreting 'the imago Dei as embodied self' (cf. Van Huyssteen 2006:145). The image of God is, in other words, 'to be human'; and to be human is 'to have a body', 'to be embodied before God', and 'as this embodied person to be open and available to God and to one another' (Van Huyssteen 2006:147). Herein, it is 'a hermeneutic of the body' (cf Van Huyssteen 2008b:505,506, 514) than, it is 'a hermeneutic of the body' argument for a 'more embodied, holistic view of human knowledge' (Van argument for a more

16.See here the excellent MTh thesis by Dunn (2016), entitled 'To know the real one' (completed in 2016, under the supervision of Robert Vosloo), with the subtitle: 'Christological promeity in the theology of Dietrich Bonhoeffer'. 
human existence. Christ's promeity is the (real) presence of Christ, in human existence, in the church, in history, and in nature (Bonhoeffer 2009:60). Neither natural theology nor creation theology can, or should, shape our theological anthropologies, for Bonhoeffer. For Bonhoeffer, already in his inaugural lecture entitled' 'Man in Contemporary Philosophy and Theology' (presented in 1930), theological anthropology takes its cue from Christology - noted Edwin Robertson (cf. Bonhoeffer 2009:10-11). Already here, in this lecture, Bonhoeffer (2009:11) argued that human beings are 'never alone', in that we exist through the community established in and by Christ.

In 'What makes us human?', Van Huyssteen (2010b) engaged Christology explicitly by 'reach[ing] deep into theology' for insights about 'the personhood and identity of Jesus Christ' in an attempt to address a central concern of interdisciplinary conversation about human uniqueness, namely 'the central theme of self and personhood' (cf. Van Huyssteeen 2010b:143). Yet, it is the relationship between Christology and (evolutionary) ethics, rather than Christology and theological anthropology, in which Van Huyssteen is interested here (as elsewhere; cf. also 'Ethics and Christology' [Van Huysteen 2008a] and 'Should we do what Jesus did?' [Van Huyssteen 2010a]).

In this contribution I am less interested in the moral trajectory of Van Huyssteen's (cf. 2008b:515-516) argument human beings developing moral awareness, and continuing to evolve (both biologically and culturally) by developing an ethics of care - and more interested in the pastoral effect of the theological rhetoric that Van Huyssteen employed. Arguably, there is a major case to be made (in more than 1000 pages, in Kelsey's case!) for a Christological interpretation of the notion of imago Dei, wherein 'Jesus Christ [is cast] as the image of God' (Kelsey 2009:1002; original emphasis). What this means is that human beings are only derivatively images (in the plural) of the image (in the singular) of God. It stands to reason that, insofar as 'imago Dei' and 'aloneness' are used interchangeably, it is Jesus who is wholly alone - as the only image of God and that human aloneness is derivative of Jesus' aloneness.

Not only could this hold greater pastoral potential for speaking about being human, but arguably this approach echoes the faith tradition not only in reference to the incarnation, but also the crucifixion, resurrection, and ascension of Jesus Christ. Stated somewhat differently, viewing Jesus Christ as 'alone in the world' ties in with or is echoed throughout the Christology section of the ecumenical creeds: not only is Jesus (alone) both fully human and fully God (and in terms of Christ's two natures, 'alone in the world'), but Jesus' abandonment on the cross (forsaken by God, and herein 'alone in the world'), resurrection from death (raised by God, and herein 'alone in the world'), ascension into heaven (sitting on the right hand of God, and herein 'alone in the world') is the heartbeat of Christian theology.
If 'disciplinary integrity' is important, together with the development of 'a public theology ... that cuts across disciplinary boundaries to facilitate optimal forms of multidisciplinary understanding' (Van Huyssteen 2008b:516), I wonder whether this may not require an uncoupling of human uniqueness to human aloneness. In this sense, we may have to go 'against the tradition' (cf. Kelsey 2009:897) by avoiding 'the traditional way of systematizing theological anthropology around the theme of the imago Dei' exactly because there may be rhetorical reasons for privileging New Testament uses, rather than Old Testament uses, of the imago Dei.

Admittedly, Van Huyssteen (2006:149) prioritised those meanings of the imago Dei that may best function within an interdisciplinary project, above those interpretations that are more suited to a specifically 'theological program with coherent intradisciplinary consequences'. Indeed, within 'the history of ideas in which the notion of the imago Dei has been embedded', there is an 'ongoing evolution of this notion' that has come to include 'very diverse and multilayered interpretations' (Van Huyssteen 2006:149). Yet, among the vast array of interpretations are also 'overly abstract, a-contextual' versions that are highly speculative and, in Van Huyssteen's view, 'exotically baroque' (Van Huyssteen 2006:149). For Van Huyssteen (2006:151), it is important to 'move away from speculative abstraction' and 'fragmented notions of self' (Van Huyssteen 2010b:150), and towards 'an integrated, embodied self' (Van Huyssteen 2010b:151).

Arguably, how we speak about human uniqueness drawing upon the imago Dei tradition - not only holds within itself possible implications for: (1) the kind of (theological) rationality required in interdisciplinary dialogue on what it means to be human (cf. Van Huyssteen 2008b:513, 2010b:143-146); or even (2) ethical implications for human action, such as requiring justice, love, and mercy (cf. Van Huyssteen 2008b:515, 2010b:155-157); but also (3) pastoral implications, towards a concern with the rhetorical power that our theological grammar exercises, and how we communicate (not only what we communicate) what it means to be human. Theology is, after all, deeply public (cf. Van Huyssteen 2010b:144).

In Wentzel van Huyssteen's theological anthropology, 'human uniqueness' and 'human aloneness' are rhetorically proximate concepts, and appear to be employed almost synonymously in Alone in the world? (Van Huyssteen 2006). As Muray (2007:302) noted, for Van Huyssteen the focus falls to human uniqueness, with 'the imago Dei being the theological side of upholding that uniqueness'. Muray is critical of the notion of human uniqueness because, in his view, it relied upon a deeply anthropocentric rhetoric: ' $[t]$ he very words human uniqueness have the connotation the difference between humans and non-humans is one of kind and not one of degree' (Muray 2007:305; original emphasis); 
and it is for this reason that Muray proposed 'human distinctiveness' as an alternative to 'human uniqueness' (Muray 2007:306).

Yet, Van Huyssteen's argument clearly showed that how we speak about human uniqueness has direct consequences for how we imagine our own aloneness in the world. The effect of our speaking about the theological idea of the imago Dei ripples not only across the landscape of interdisciplinary dialogue, but also across the landscape of Christian doctrines and the landscape of the everyday, lived experiences of ordinary believers.

\section{Conclusion}

Wentzel van Huyssteen and David Kelsey both employ metaphors to clarify their interpretation of the imago Dei, and in particular how they envision their argument performing rhetorically. A variety of metaphors for the imago Dei can and have been employed, including the 'more traditional picture of the imago Dei as a mirror reflecting God' (Van Huyssteen 2006:157). Instead of a mirror, however, Wentzel van Huyssteen proposed the image (borrowed from Richard Middleton) of a prism, which is continually 'refracting the concentrated light of God's glory through a multitude of human sociocultural activities' (Van Huyssteen 2006:157). For David Kelsey, who also referred to the image of a mirror (cf. Kelsey 2009:997-999), but then explains that his project employed the image of a triple helix to elucidate the ways in which 'human beings, not bearing the image of God themselves, nonetheless image the image of God' (Kelsey 2009:1009). ${ }^{17}$ Such images bear witness to the ongoing importance of a vibrant theological imagination - which is a key priority for both David Kelsey and Wentzel van Huyssteen towards meeting the challenges (including the ecological crisis), and questions (including the question: Are we alone in the world?), of our time.

\section{Postscript}

I am a young South African theologian, and I would like to mention this specifically when I thank Wentzel van Huyssteen for his advice, his kindness, and his mentorship over the years. From the moment when I encountered his Alone in the World? (in an MTh exam, even before meeting him), I was intrigued and inspired by his theological creativity and his concern for dialogue between science and theology. Thank you, Wentzel - and happy birthday!

17.In a chapter with the subtitle "Imago Dei as Triple Helix (Kelsey 2009:895-921) Kelsey sets out a detailed account of what he meant with this image of a triple helix. In short, he envisioned a helix structure - 'having a three-dimensional shape like that of a wire wound uniformly around a cone or a cylinder' (Kelsey 2009:897)but instead of a closed off, open-ended (Kelsey 2009:898). The three parts of his project wound together like 'two or more helices [that spiral around one another]" (Kelsey 2009:898), but in a very specific order: whereas part 2 (God drawing human beings into eschatological consummation) and part 3 (God redeeming human beings) are wound around one another in a double helix as those parts of human's projs are wound Kelsey's project that share a narrative logic, namely the life and work of Jesus of Nazareth; part 1 God creating human beings) forms a helix on its own, as a distinct narrative parts 2 and 3 spiral around each other 'to form a triple helix' (Kelsey 2009:899). See also a previous article in which I explored this, entitled "Imaging the Image of God": David H. Kelsey oor die Imago Dei' (cf. Marais 2013).

\section{Acknowledgements Competing interests}

The author declares that she has no financial or personal relationships that may have inappropriately influenced her in writing this article.

\section{Author's contributions}

N.M. is the sole author of this article.

\section{Ethical considerations}

This article followed all ethical standards for research without direct contact with human or animal subjects.

\section{Funding information}

This research received no specific grant from any funding agency in the public, commercial or not-for-profit sectors.

\section{Data availability}

Data sharing is not applicable to this article as no new data were created or analysed in this study.

\section{Disclaimer}

The views and opinions expressed in this article are those of the author and do not necessarily reflect the official policy or position of any affiliated agency of the author.

\section{References}

Bonhoeffer, D., 2009, Christ the center (Harper's Ministers Paperback Library), transl. (of Wer is und wer war Jesus Christus) E. H. Robertson, HarperOne, San Francisco, CA

Dunn, P., 2016, 'To know the real one: Christological Promeity in the theology of Dietrich Bonhoeffer', MTh thesis, Stellenbosch University.

Durand, J.J.F., 1981, Skepping, mens, voorsienigheid, Wegwysers in die Dogmatiek, vol. 5, NG Kerkboekhandel, Pretoria.

Fergusson, D., 2015, 'Are we alone? And does it matter?', Theology Today 72(2), 194-205. https://doi.org/10.1177/0040573615581546

Frei, H.W., 2013, The identity of Jesus Christ: The Hermeneutical bases of dogmatic theology, updated and expanded edn., Cascade Books, Eugene, OR.

Fulkerson, M.M., 1997, 'Contesting the gendered subject: A feminist account of the Imago Dei', in R.S, Chopp \& S.G. Davaney (eds.), Horizons in feminist theology: Identity, tradition and norms, pp. 99-116, Augsburg Press, Minneapolis, MN.

Grenz, S., 2001, The social God and the relational self: A Trinitarian theology of the imago Dei, Westminster John Knox Press, Louisville, KY.

Kelsey, D.H., 2009, Eccentric existence: A theological anthropology, Westminster John Knox Press, Louisville, KY

Lilley, C. \& Pedersen, D.J. (eds.), 2017, Human origins and the image of God: Essays in honour of J. Wentzel van Huyssteen, William B. Eerdmans Publishing Company, Grand Rapids, MI.

Marais, N., 2013, “'Imaging the image of God”: David H. Kelsey oor die Imago Dei', Nederduitse Gereformeerde Teologiese Tydskrif 54(1\&2), 1-14. https://doi. org/10.5952/54-1-2-314

McFadyen, A.l., 1990, The call to personhood, Cambridge University Press, Cambridge.

McFarland, I.A., 2001, Difference and identity, Pilgrim Press, Cleveland, OH.

Muray, L.A., 2007, 'Human uniqueness vs. human distinctiveness: The "Imago Dei" in the Kinship of all creatures', American Journal of Theology \& Philosophy 28(3), 299-310.

Outka, G. (ed.), 2016, The theological anthropology of David Kelsey: Responses to Eccentric Existence, William B. Eerdmans Publishing Company, Grand Rapids, MI. 
Van Huyssteen, J.W., 2006, Alone in the world? Human uniqueness in science and theology, The Gifford Lectures, the University of Edinburgh, 2004, William B. theology, The Gublishing Company, Grand Rapids, MI.
Eerdmans Publect

Van Huyssteen, J.W., 2008a, 'Ethics and Christology - Rediscovering Jesus in evolutionary history', Verbum et Ecclesia 29(2), 492-506. https://doi.org/10.4102/ve.v29i2.45

Van Huyssteen, J.W., 2008b, 'Primates, Hominids, and humans - From species specificity to human uniqueness? A response to Barbara J. King, Gregory R Peterson, Wesley J. Wildman, and Nancy R. Howell', Zygon 43(2), 505-525. https://doi.org/10.1111/j.1467-9744.2008.00931.x
Van Huyssteen, J.W., 2010a, 'Should we do what Jesus did? Evolutionary perspectives on Christology and ethics', in F.L. Shults \& B. Waters (eds.), christology and ethics, pp. 149-178, William B. Eerdmans Publishing Company, Grand Rapids, MI.

Van Huyssteen, J.W., 2010b, 'What makes us human? The interdisciplinary challenge to theological anthropology and Christology', Toronto Journal of Theology 26(2), 143-160. https://doi.org/10.3138/tjt.26.2.143

Van Huyssteen, J.W., 2015, 'A response to my colleagues', Theology Today 72(2):206-226. https://doi.org/10.1177/0040573615586283 